\title{
Tarımsal Arazilerin Miras ve Satış Yoluyla Devrinde Anlaşmazlık Durumları ve Çözüm Önerileri
}

\section{İsmet İpek KAVASOĞLU Cengiz SAYIN D \\ Akdeniz Üniversitesi, Ziraat Fakültesi Tarım Ekonomisi Bölümü, Antalya \\ 凹: csayin@akdeniz.edu.tr}

\author{
Makale Tarihçesi \\ Geliş : 20.10.2018
}

Kabul : 27.12.2018

\author{
Anahtar Kelimeler \\ Tarımsal Arazi, \\ Miras, \\ Satış Izni, \\ Mülkiyet Devri, \\ 6537 Sayılı Kanun
}

\section{Araştırma Makalesi}

\section{Conflict Situations and Solutions on Assinging Through Heritage and Sales of Agricultural Land} \begin{abstract}
In order to prevent the fragmentation of agricultural lands by inheritance and sales the use of agricultural lands for non-agricultural purposes, Turkey has established the Law No. 6537 concerning Soil Conservation and Land Use. Therefore, the Ministry of Agriculture and Forestry has in charge the attribution and information for relevant units of agricultural land in order to transfer the property both from sales and inheritance. Accordingly, the transfer of land takes into consideration the land size limitations, such as minimum agricultural land, sufficient agricultural income and economic integrity. However, the applicants for the sale permit face many difficulties in determining the land size limits as well as the transfer to inheritance encounters many disputes. So, this situation makes the implementation of the inheritance Law complicated and becomes prominent issue which requires urgent solution in the country's agenda. This study aims to evaluate the causes of disputes over land transfer and to suggests solutions to resolve land ownership's issues. Primary data through survey was used in the current research and the findings reveal that the main disagreements arise from the existing law in the province of Antalya.
\end{abstract}

Article History
Received : 20.10.2018
Accepted : 27.12 .2018
Keywords
Agricultural Land,
Heritage
Sales Permit,
Ownership Transfer,
Law: 6537

\section{Research Article}

To cite: Kavasoğlu İİ, Sayın C 2018. Tarımsal Arazilerin Miras ve Satış Yoluyla Devrinde Anlaşmazlık Durumları ve Çözüm Önerileri. KSÜ Tar Doğa Derg 21(Özel Sayı) : 133-145, DOI : 10.18016/ ksutarimdoga.vi.472823

\section{GİİŞ}

Geçmişten bu yana, Türkiye'de mirasa konu tarım işletmelerini ilgilendiren Medeni Kanun hükümleri, tarım topraklarının miras hukukunun genel hükümlerine göre paylaştırılmasının istisnası olarak nitelendirilmiştir. Ancak uygulanmak istenen bu hükümlerin mirasçıların isteğine bırakılması, diğer taraftan mirasa konu tarım işletmesinin hukuki tanımının ve ekonomik sinırlarının yasal yapı içerisinde uzun yıllar yer bulamaması, miras yoluyla 
tarım arazilerinin bölünmesini ve tarım işletmelerinin ölçeklerinde küçülmelerin yaşanmasını beraberinde getirmiştir. Gelinen noktada, tarım işletmelerinin parçalı ve dağınık bir halde ekonomik bütünlükten uzaklaşması sonucunda tarımın sürdürülebilirliği olumsuz yönde etkilenirken, hukuki açıdan alınacak önlemlerde tarım işletmesi bütünlüğünden ziyade tarım arazilerinin bölünmesinin önlenmesi üzerinde odaklanılmıştır (Sayın, 2018).
Medeni Kanun içerisinde ve miras hukuku kapsamında yer alan tarıma yönelik özel düzenlemeler yanında, Çizelge 1'de görüldüğü gibi kamu hukuku alanında da pek çok yasal düzenleme gerçekleştirilmiş ve son olarak 2014 yılında 6537 Sayılı Toprak Koruma ve Arazi Kullanımı Kanununda Değişiklik Yapılması Hakkında Kanun yürürlüğe girmiştir.

Çizelge 1. Tarım arazilerinde miras yoluyla parçalanmasını önleyici kamu hukuku kapsamlı yasal düzenlemeler (Sayın, 2018)

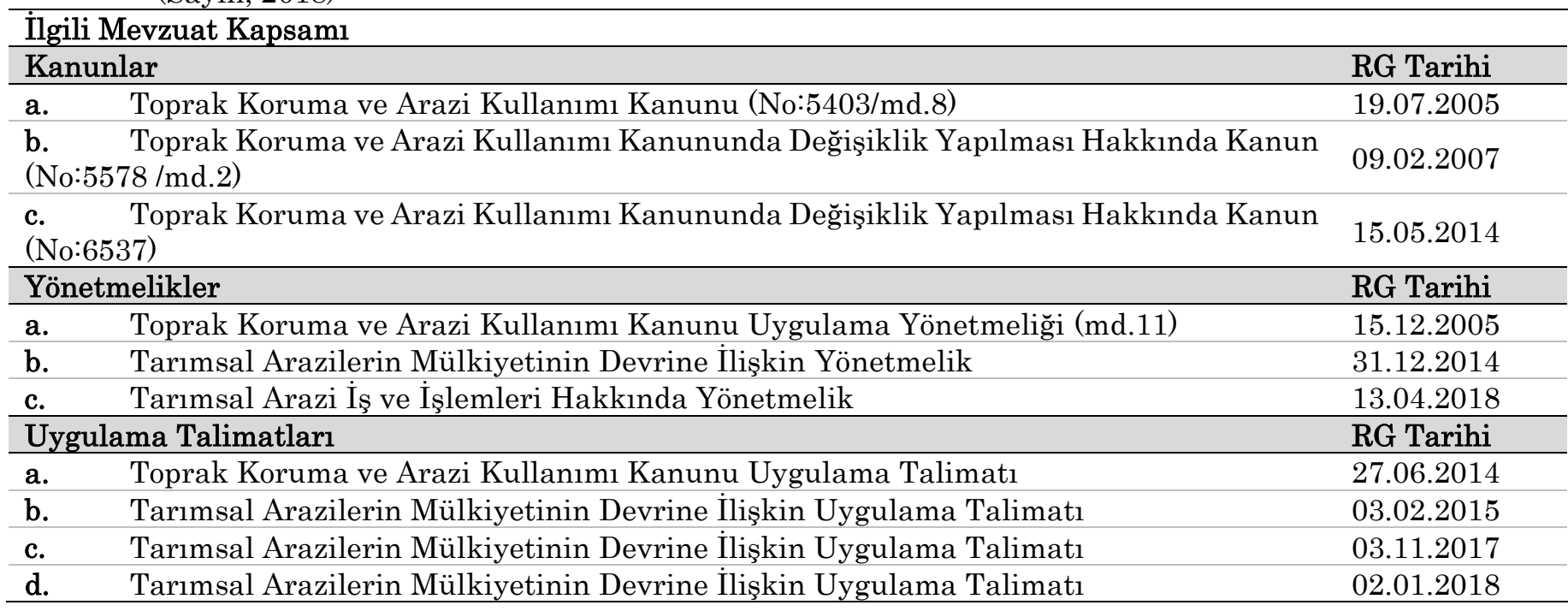

Kamuoyunda "Yeni Miras Kanunu" olarak anılan 6537 Sayılı Kanun'un 9. Maddesi gereğince Medeni Kanun'un söz konusu mirasa ilişkin kurallarını belirleyen maddeleri, yürürlükten kaldırılmıştır. Kanun ile getirilen söz konusu değişikliklerde mirasa konu tarım arazilerinde mülkiyet devri zorunlu ve süre bakımından kisıtlı tutulmuştur. Bu anlamda, mirasa konu olan tarım arazilerinin mülkiyet devri sorununun en kısa zamanda çözüme ulaştırılacağ amaçlanmış, tarımsal arazilerin hem satış hem de miras yoluyla mülkiyet devri konusunda Tarım ve Ormancılık Bakanlığı'nın ilgili birimlerinden izin alınması kanunca hüküm altına alınmıştır. Kanuna göre, gerek miras gerekse satış amaçlı yapılan devir başvurularında Bakanlıkça izin verilen arazi büyüklük sinırlılıkları, asgari tarımsal arazi büyüklüğü olarak; mutlak tarım arazileri, marjinal tarım arazileri ve özel ürün arazilerinde 2 hektar, dikili tarım arazilerinde 0,5 hektar, örtü altı tarımı yapılan arazilerde 0,3 hektar olarak belirlenmiştir (Resmi Gazete 2014a/madde 4). Yeter gelirli tarımsal arazi büyüklüğü olarak; tüm ülke genelinde ilçeler düzeyinde kuru arazi, sulu arazi, dikili arazi ve örtüaltı araziler için bölünmeye karşı alt sınırlar ilan edilmiştir (Resmi Gazete 2014a/madde 5). Kanun uygulaması kapsamında yürürlüğe giren yönetmelik ile beraber getirilen ekonomik bütünlük sinırları ise aynı kişiye ait tarımsal arazilerden örtü altında 1 dekar, dikili arazide 5 dekar, sulu ve kuru tarım arazilerinde 10 dekarın altında olan arazilerin ekonomik bütünlük oluşturmayacağı kararlaştırılmış, bu sınırların değiştirilmesi, asgari ve ekonomik bütünlük için Bakanlık kararına, yeter gelir için ise Bakanlar Kurulu Kararı'na bağlanmıştır (Resmi Gazete 2014b/madde7).

Kanun uygulaması kapsamında öne çıkan bir başka konu ise, miras kalan tarımsal arazilerin devrinde mirasçılara anlaşmalı devir seçenekleri tercihinin getirilmesidir. Buna göre; miras kalan araziler için tek mirasçıya, birden fazla mirasçıya (yeter gelirli arazi büyüklük sınırları gözetilerek), aile malları ortaklığının ya da limited şirketin kurulmasına veya üçüncü kişilere satış şeklinde devrine karar verilebilmektedir (Resmi Gazete 2014a/madde 5). Ayrıca mirasçılar arasında anlaşma sağlanmaması halinde veya verilen yasal sürelerin bitiminde Bakanlıkça dava açılması durumunda da ilgili mahkemece verilebilecek devir kararları kanunda belirlenmiştir (Resmi Gazete 2014a/madde 5).

Tarım Reformu Genel Müdürlüğü (2017) verilerine göre, Türkiye'de toplam 23,8 milyon hektar tarım arazisi üzerinde 40 milyondan fazla hissedarın varlığı söz konusu iken fiili kullanıcı sayısı ise 3 milyon olarak ifade edilmektedir. Mirasa söz konusu olan arazilerde mülkiyet devrinin anlaşmalı devir seçenekleri tercihine göre zorunlu tutulması, hissedar sayısının 
fazla olduğu ülke genelinde uygulamada en çok karşılaşılan sorun alanının anlaşmazlık hallerinin çözümünde olduğu öne çıkarken, hem satış hem de mirasla devir amaçlı yapılan başvurularda da arazi büyüklük sınırları konusunun çözüme kavuşturulması gerekmektedir.

$\mathrm{Bu}$ çalışmayla tarımsal arazilerin miras ve satış yoluyla devrinde anlaşmazlık durumlarının çözümüne yönelik önerilerin belirlenmesinde, Antalya ili örtüaltı üreticilerinin kanun uygulamasına ilişkin tutum ve görüşlerinden elde edilen veriler ile tartışılması amaçlanmıştır.

\section{MATERYAL ve METOT}

\section{Materyal}

Çalışmanın birincil veri kaynağı olan alan bulguları, 6537 Sayılı Kanun nedeniyle mülkiyet devri yapmak zorunda olup tapu veya tarım il/ilçe müdürlüklerine başvuru yapmış, Antalya ili Kumluca, Serik ve Aksu ilçelerindeki örtüaltı üreticilerinden sağlanan orijinal anket verileri oluşturmaktadır. İkincil veri kaynakları olarak; Tarım ve Ormancılık Bakanlığı (TOB), Tarım
Reformu Genel Müdürlüğü (TRGM) ve Tapu Kadastro Genel Müdürlüğü kaynaklarından, hukuki durum için ise ilgili mevzuat (kanun, yönetmelik, uygulama talimatları) ve bilimsel araştırmalardan yararlanılmıştır.

\section{Metot}

Veri toplama yöntemi

Kanun uygulamasının yürülüğe girdiği tarih itibariyle 2015-2017 yılları arasında ülke genelinde satışla mülkiyet devri için yapılan toplam başvuru sayısı 977.939 ve alan miktarı ise 3,63 milyon hektar, miras yoluyla mülkiyet devri için yapılan toplam başvuru sayısı 79.127 ve alan miktarı 1,58 milyon hektardır (Tarım Reformu Genel Müdürlüğü, 2017). Örtüaltı tarım arazisi örneğine ilişkin Antalya ilinin araştırma yapılacak yer ve alanın belirlenmesinde; örtüaltı alan/üretim miktarları ile ülke geneli toplam devir rakamlarında satış ve mirasla devir başvuruları dikkate alınarak Kumluca, Serik ve Aksu ilçeleri tercih edilmiştir (Çizelge 2).

Çizelge 2. Türkiye, Antalya ve araştırma alanı arazi mülkiyet devri işlemleri (Tarım ve Ormancıllk Bakanlığı, 2017)

\begin{tabular}{lcccccc}
\hline & Satışla Devir & \multicolumn{3}{c}{ Mirasla Devir } & \multicolumn{3}{c}{ TOPLAM } \\
\cline { 2 - 7 } & $\begin{array}{c}\text { Başvuru } \\
\text { Sayısı (kişi) }\end{array}$ & $\begin{array}{c}\text { Tarım Alanı } \\
\text { (dekar) }\end{array}$ & $\begin{array}{c}\text { Başvuru } \\
\text { Sayısı (kişi) }\end{array}$ & $\begin{array}{c}\text { Tarım Alanı } \\
\text { (dekar) }\end{array}$ & $\begin{array}{c}\text { Başvuru Sayısı } \\
\text { (kişi) }\end{array}$ & $\begin{array}{c}\text { Tarım Alanı } \\
\text { (dekar) }\end{array}$ \\
\hline Kumluca & 3.049 & 9.607 & 301 & 985 & 3.350 & 10.052 \\
\hline Serik & 4.325 & 14.994 & 358 & 1.559 & 4.683 & 19.677 \\
\hline Aksu & 4.384 & 70.180 & 360 & 10.442 & 4.744 & 80.622 \\
\hline Antalya & 48.457 & 281.020 & 6.335 & 40.453 & 54.792 & 321.473 \\
Türkiye & 977.939 & 36.342 .581 & 79.127 & 1.584 .810 & 1.057 .066 & 37.928 .391 \\
\hline
\end{tabular}

Örnek büyüklüğü ve araştırma uygulanan üreticilerin belirlenmesinde, Kanun (6537) sonrası her üç ilçede toplam başvuru sayısı bilinmesine karşın, bilgi gizliliği nedeniyle diğer işletme bazlı veriler temin edilemediğinden "kartopu örnekleme yöntemi" tercih edilmiştir. Kartopu (zincir) örnekleme yöntemi; araştırmaya konu ana popülasyonun tam olarak belirlenemediği durumlarda popülasyonu temsil edecek örneği belirlemek için kullanılmaktadır (Kılıç ve Ural 2013).

Kanun (6537) uygulaması kapsamına giren üreticilere ulaşlmasında, bölgeye ve konuya hakim olan Bakanlık ilçe personelleri, muhtarlar, tapu ve harita kadastro mühendisleri ile görüşülmüştür.

Veri toplama yöntemi olarak ise yüz yüze görüşmeye dayalı anket yöntemi kullanılarak toplam örnek sayısının en az 100 üretici olarak belirlendiği anket uygulamasında, üç ilçenin toplam başvuru sayısındaki paylarına göre oransal olarak dağılımı dikkate alınarak örnek sayısının oluşması planlanmış, bunun da dörtte üçünün (75 üretici), araştırmanın ana amacı ve araştırmada ele alınacak konuların ağırlıklı bölümünü oluşturmasından dolayı mirasla devir amaçlı başvuranlardan elde edilmesi öngörülmüştür. Ancak, araştırma yapilan konunun kamuoyunda hassasiyetle karşlanması nedeniyle üreticilerin önemli bölümü ankete katılma konusunda tereddütlü davranmışlardır. Bazı üreticilerin de miras kalan arazilerin mülkiyet devri işlemlerini takipçiler (muhtar, avukat, emlakçı gibi) aracılığıyla yaptırmış oldukları görülmüştür. Elde edilen anket verilerinin araştırmanın amacına uygun olarak sağlıklı bir sonuç vermeyeceği düşünüldüğünden, doğrudan konuyla ilgili bilgisi olan üreticilerle anket yapılması yolu tercih edilmiştir. Sonuçta 88 üretici ile anket yapılabilmiştir. Bunlardan 68'i miras yoluyla intikal başvurusu yapan tarım arazisi varisi ve 20'si satış amaçlı devir yapan üreticilerdir. Anket sayılarının ilçelere göre oransal dağılımı Çizelge 3 ’te görüldüğü gibidir. 
Çizelge 3. Araştırma yapılan ilçelere göre üretici sayısı dağılımı

\begin{tabular}{lllll}
\hline İlçeler & \multicolumn{2}{c}{ Miras Yoluyla Devir Anketi Üretici Sayısı } & \multicolumn{2}{c}{ Satış Yoluyla Devir Anketi Üretici Sayısı } \\
\cline { 2 - 5 } & Frekans & $(\%)$ & Frekans & $(\%)$ \\
Aksu & 14 & 20,6 & 16 & 80,0 \\
Serik & 38 & 55,9 & 2 & 10,0 \\
Kumluca & 16 & 23,5 & 2 & 10,0 \\
Toplam & $\mathbf{6 8}$ & $\mathbf{1 0 0 , 0}$ & $\mathbf{2 0}$ & $\mathbf{1 0 0 , 0}$ \\
\hline
\end{tabular}

Verilerin analizi yöntemi

6537 Sayılı Kanun ile tarımsal arazilerin miras ve satı̧̧ yoluyla devrinde anlaşmazlık durumlarını belirleme "5’li likert tipi tutum ölçeği" kullanılmıştır. Likert tipi ölçek yöntemi; çoğunluklu sosyal araştırmalarda tercih edilen ve çok sık kullanılan ölçekleme yöntemlerinden birisi olup herhangi bir olguya karşı farklı derecelerde hazırlanmış seçenekler tablosu olarak tanımlanmaktadır (Sayın, 2018).

\section{BULGULAR ve TARTIŞMA}

\section{Saylı Kanun kapsamı ve uygulaması}

Toprak Koruma ve Arazi Kullanımı Kanununa yönelik 2014 yılında yapılan son değişiklikle 6537 Sayılı Kanun yürürlüğe girmiş, kanun ile beraber pek çok yeni düzenlemeler getirilerek tarımsal arazilerin miras yoluyla intikallerinde mülkiyet devrini esas alan bazı yeni uygulamalar getirilmiştir. Bu uygulama kapsamında, gerek miras gerekse satış yoluyla devirlerde anlaşmazlık durumlarına yönelik öne çıkan dört temel alan mevcut yasal yapı içerisinde irdelenmiştir.

Tarımsal arazilerde bölünme yasağı ve arazi büyüklük sinirlamaları

Tarım arazilerinin gerek satı̧̧ gerekse miras yoluyla bölünerek parçalanmasının önlenmesinde 6537 Sayılı Kanun'la yapılan değişikler kapsamında asgari ve yeter gelirli tarımsal arazi büyüklüklerine yer verilerek tarım arazilerinde bölünme yasağ getirilmiştir. Tarımsal arazilerde bölünme yasağı bakımından 2000'li yıllardan beri yasal yapı içinde ele alınan arazi büyüklük sınırları Çizelge 4’te verilmiştir.

Çizelge 4. Türkiye'de tarımsal arazi büyüklük sınırlılıklarının yasal yapı içinde değerlendirilmesi (Sayın, 2018)

\begin{tabular}{|c|c|c|c|c|c|c|}
\hline \multirow[b]{2}{*}{$\begin{array}{l}\text { Arazi Sinıfi } \\
\text { Tanımlamaları }\end{array}$} & \multicolumn{4}{|c|}{ Arazi Büyüklük Sınırları (Dekar) } & \multirow[b]{2}{*}{ İlgili Mevzuat } & \multirow[b]{2}{*}{$\begin{array}{l}\text { Yürürlük } \\
\text { Tarihi }\end{array}$} \\
\hline & $\begin{array}{l}\text { Mutlak ve Özel } \\
\text { Ürün Tarım } \\
\text { Arazileri }\end{array}$ & $\begin{array}{c}\text { Dikili } \\
\text { Tarım } \\
\text { Arazileri }\end{array}$ & $\begin{array}{l}\text { Örtüaltı } \\
\text { Tarım } \\
\text { Arazileri }\end{array}$ & $\begin{array}{l}\text { Marjinal } \\
\text { Tarım } \\
\text { Arazileri }\end{array}$ & & \\
\hline \multirow{5}{*}{$\begin{array}{l}\text { Tarımsal Arazi } \\
\text { Parsel } \\
\text { Büyüklüğü }\end{array}$} & 10 & 5 & 3 & 20 & $\begin{array}{l}\text { Tarım İşletmelerinin Yeterli } \\
\text { Tarımsal Varlığa Sahip Olup } \\
\text { Olmadığının Tespitine Dair } \\
\text { Yönetmelik/madde } 7\end{array}$ & 26.01 .2003 \\
\hline & 10 & 5 & 3 & 20 & $\begin{array}{l}\text { Yeter Gelirli Tarımsal İşletme } \\
\text { Büyüklüklerinin Tespitine Dair } \\
\text { Tebliğ/madde.11 }\end{array}$ & 30.06 .2003 \\
\hline & - & - & - & - & 5403 Sayılı TKAKK/ madde 8 & 19.07 .2005 \\
\hline & 10 & 5 & 3 & 20 & $\begin{array}{l}5403 \text { Sayll TKAKK Uygulama } \\
\text { Yönetmeliği/madde } 11\end{array}$ & 15.12 .2005 \\
\hline & 20 & 5 & 3 & 20 & $\begin{array}{l}5403 \text { Sayll TKAKK Değişiklik } \\
\text { Yapılması Hakkında Kanun } \\
\text { (No:5578/madde 2) }\end{array}$ & 09.02 .2007 \\
\hline $\begin{array}{l}\text { Asgari Tarımsal } \\
\text { Arazi } \\
\text { Büyüklüğü }\end{array}$ & 20 & 5 & 3 & 20 & $\begin{array}{l}5403 \text { Sayılı TKAKK Değişiklik } \\
\text { Yapılması Hakkında Kanun } \\
\text { (No:6537/madde 4) }\end{array}$ & 15.05 .2014 \\
\hline $\begin{array}{l}\text { Yeter Gelir } \\
\text { Tarımsal Arazi } \\
\text { Büyüklüğü }\end{array}$ & \multicolumn{4}{|c|}{ İl ve İlçelere Göre Ek (1) Sayılı Liste } & $\begin{array}{l}\text { 5403 Sayllı TKAKK Değissiklik } \\
\text { Yapılması Hakkında Kanun } \\
\text { (No:6537/madde 5 }\end{array}$ & 15.05 .2014 \\
\hline $\begin{array}{l}\text { Ekonomik } \\
\text { Bütünlük Arazi } \\
\text { Sınırı }\end{array}$ & \multicolumn{4}{|c|}{$\begin{array}{l}\text { - Aynı kişiye ait sınırdaş olmayan araziler arası } \\
\text { mesafe max. } 10 \mathrm{~km} \text {, } \\
\text { • Örtüaltı } 1 \mathrm{da} \text {, dikili } 5 \mathrm{da} \text {, ekili } 10 \text { da ve üzerinde } \\
\text { ekonomik bütünlük kabul edilir. }\end{array}$} & $\begin{array}{l}\text { Tarımsal Arazilerin } \\
\text { Mülkiyetinin Devrine İlişkin } \\
\text { Yönetmelik/madde } 7\end{array}$ & 31.12 .2014 \\
\hline
\end{tabular}

Kanuna göre, asgari tarımsal arazi büyüklüğü “...... Bakanlıkça belirlenen en küçük tarımsal parsel büyüklüğ̈̈’olarak ifade edilerek arazi sinıflarma göre bölünemez sinırlar getirilirken; bölge farklılıkları gözetilerek il ve ilçe bazında yeter gelirli tarımsal arazi büyüklükleri ilan edilmiştir (Resmi Gazete 2014a/madde 4). Mirasa veya satışa konu tarım arazilerinin devrinde, 6537 sayılı Kanun'un getirdiği önemli değişikliklerden biri de "ekonomik bütünlük" 
kısıtlamasıdır. "Tarımsal Arazilerin Mülkiyetinin Devrine İlişkin Yönetmelik" ile düzenlenen ekonomik bütünlük kavramı, "mülkiyeti aynı kişiye ait birden fazla tarımsal arazinin tarımsal üretim faaliyetine ekonomik bir değer katacak şekilde birbirine bă̆ıml olarak işletildiğ̈ Bakanlıkça tespit edilen araziler" olarak tanımlanmıştır (Resmi Gazete 2014b/madde 4).

\section{Mirasa konu tarımsal arazilerin mülkiyet devri}

Mirasa konu tarımsal arazilerin mülkiyet devrinin zorunlu bırakılması 6537 Sayılı Kanun'la öne çıkan en köklü değişiklik olarak nitelendirilirken, zorunlu olan mülkiyet devri de kanunun öngördüğü anlaşmalı devir seçeneklerine göre mirasçıların tercihine sunulmuştur (Sayın, 2018). Kanuna göre, mirasa konu tarımsal arazilerin mülkiyet devri işlemlerinin mirasın açılmasından itibaren bir yıl içinde tamamlanması gerekmektedir (Resmi Gazete 2014a/madde 5). Mirasçılar aralarında anlaşma sağlayarak kanunun sunduğu devir seçeneklerine göre mülkiyet devrini gerçekleştirirler. Buna göre mirasçılar, "bir mirasçıya, yeter gelirli tarımsal arazi büyüklüklerini karşılaması durumunda birden fazla mirasçıya, 22/11/2001 tarihli ve 4721 sayılı Türk Medenî Kanununun 373. üncü ve devamı maddelerine göre kuracakları aile malları ortaklı̆̆gna veya kazanç paylı aile malları ortaklı̆̆gna, mirasçıların tamamının miras payı oranında hissedarı oldukları 13/1/2011 tarihli ve 6102 sayll Türk Ticaret Kanunu hükümlerine göre kuracakları limited şirkete veya mülkiyetin üçüncü kişilere devrini" kararlaştırabilirler (Resmi Gazete 2014a/madde 5).

Mirasçılar arasında anlaşma sağlanamaması halinde ise mirasçlardan her birinin yetkili sulh hukuk mahkemesi nezdinde dava açabileceği belirtilmiş, bununla birlikte mirasçılar tarafından tarımsal arazilere ilişkin mülkiyet devirlerinin bir yıl içinde tamamlanmaması halinde, Bakanlık tarafindan mirasçılara tebligat gönderilerek Kanun hükümlerinin uygulanması için 3 aylık daha ek süre verileceği kuralı getirilmiştir.

$\mathrm{Bu}$ süre sonunda devir işlemlerinin tamamlanmaması durumunda da, Bakanlığın doğrudan veya bildirim üzerine bu yerlerin istemde bulunan ehil mirasçıya, ehil mirasçı olmaması durumunda en fazla teklifi veren istekli mirasçıya devri, aksi halde üçüncü kişilere satılması için ilgili sulh hukuk mahkemesi nezdinde dava açabileceği hüküm altına alınmıştır.

Dava açılması halinde mahkemenin devir kararına ilişkin seçenekler ise Kanun kapsamında ele alınan konular arasındadır (Resmi Gazete 2014a/madde 5).

Mirasçllar veya Bakanlık tarafindan dava açılması halinde, sulh hukuk hakimi devir kararında ehil mirasçıya öncelik tanımaktadır (Özçelik 2015). Ehil mirasçı; "kişisel yetenek ve durumları göz önünde tutulmak suretiyle bu Yönetmelik hükümlerince belirlenen kriterlere uygun sulh hukuk mahkemesi tarafindan belirlenen mirasçı veya mirasçılara" denir (Resmi Gazete 2014b/madde 4). Buna göre, Yönetmelik ile belirlenen ehil mirasçıya ait kriterlerden 50 puan ve üstüne sahip olan mirasçı veya mirasçılar, ehil olarak kabul edilmektedir (Resmi Gazete 2014b/madde 4).

Tarımsal arazilerin satış yoluyla devri ve satış izni uygulaması

Satışa konu tarım arazilerinin mülkiyet devri işlemlerine ilişkin uygulama esasları, Kanun'un ardından yürürlüğe giren Yönetmelik ile belirlenerek (Resmi Gazete 2014b) bir tarım arazisinin satış işleminin uygun olup olmaması Bakanlık izni ile denetim altına alınmaya çalışılmıştır (Sayın, 2018). Satış izni uygulamasında Bakanlık iznine tabi olan devir işlemlerinin uygun olup olmadığının tespitinde öne çıkan temel kriter, tarımsal arazilerde bölünme yasağı getirilen arazi büyüklük sınırlarıdır. Miras yoluyla gerçekleşen intikallerde olduğu gibi satış yoluyla mülkiyet devri taleplerinde, Kanun'da (6537) belirtilen yeter gelirli tarımsal arazi büyüklükleri altında parsel ve hisse oluşması engellenerek, tarımsal arazilerin ekonomik bütünlüğünün korunması amaçlanmıştır (Sayın, 2018).

Satış yoluyla devir işlemleri içerisinde ele alınan diğer bir konu da şuf'a (önalım) hakkının sınırdaş arazi sahiplerine tanınmasıdır. Satın alma önceliğinin verildiği sınırdaş arazi sahiplerine bu durumda mevcut arazi varlıklarını genişletebilme imkânı sağlanmıştır.

Tarım arazilerinin hisseli ve bölünerek satılmasını önlemeyi amaçlayan satış usullerinin belirlendiği bir konu da tarımsal faaliyetin sonlandırılması tercihidir. $\mathrm{Bu}$ durumda, arazi malikinin tarımsal faaliyete son vermek istemesi halinde yürütülmesi gereken işlemler, Yönetmelik (Resmi Gazete 2014b/madde 13) ve Uygulama Talimatı (Resmi Gazete 2017/Talimat/Bölüm 3) kapsamında düzenlenirken, tarımsal arazi malikleri için sahibi oldukları arazilerin tamamını elden çıkarmak suretiyle tarımsal faaliyete son verebilecekleri belirtilmiştir.

\section{Arazi edindirme iş ve işlemleri}

Bakanlık yönergesi ile kurulan, "Arazi Edindirme Şube Müdürlükleri” tarafindan yapılacak ya da yaptırılacak olan uygulamaya yönelik arazi edindirme iş ve işlemleri, 2018 tarihli "Tarımsal Arazi Edindirme İş ve İşlemleri Hakkında Yönetmelik" ile yeniden düzenlenmiştir. Son olarak "Arazi Toplulaştırma ve Tarımsal Altyapı Şube Müdürlükleri” olarak adı değiştirilen ofisler, halen Kanun uygulamasının yürütülmesinde her türlü iş ve işlemlerden sorumlu olan Bakanlık birimidir. 


\section{Alan bulguları}

6537 Sayılı Kanun uygulamasının üreticilere yansımalarında öne çıkan anlaşmazlıklar ve sorun alanlarının belirlenmesinde Antalya ili örtüaltı işletmeleri örneğinde 88 üretici ile anket uygulaması yürütülmüştür. Tapu il/ilçe müdürlüklerine veya Bakanlık il/ilçe müdürlüklerine devir başvurusu yapmış üreticiler, mirasla devir ve satışla devir olarak iki ayrı gruba ayrılarak anket uygulanmıştır. Bu üreticilerin 68'i miras amaçlı intikal başvurusu yapan, 20 'si ise satış amaçlı devir başvuru yapan üreticilerdir. Üretici sayılarının ilçelere göre dağılımı Çizelge 3’te verilmiştir.

Miras anketi araştırma bulgularına göre; toplam 68 üreticiden 52'si diğer varislerle anlaşma sağlayan 16'sı ise anlaşmazlık durumunda olan üreticilerdir.

Miras yoluyla mülkiyet devrinde öne çıan üretici tutumu bulguları

Miras yoluyla yapılan intikal işlemlerinde tapu müdürlüklerine yapılan başvuruların, $\% 73,5 \% \mathrm{i}$ varis (üretici) tarafından yapılır iken, \%26,5’i takipçiler tarafindan yapılmıştır. Anket uygulanan bölge bazında takipçilerin kimler olduğu da değişiklik göstermiş, Aksu ilçesi için çoğunlukla muhtarların veya emlakçıların, Serik ilçesi için tapu kadastro işlemleri ile ilgilenen kişi ve emlakçıların, Kumluca ilçesinde de harita kadastro mühendisleri ile beraber emlakçıların bu işlemleri yürüttüğü gözlemlenmiştir.

Kanun hakkında üretici bilgi düzeyi ve bilgi kaynakları

Mirasa konu tarım arazilerinde 6537 Sayılı Kanun uygulamasının getirdiği düzenlemelerin bütünü hakkında üreticilerin bilgi düzeyleri Çizelge 5'te verilmiştir. Üreticilerden \%8,8'inin düzenlemeler hakkındaki bilgisi çok yetersiz iken, \%44,1'inin yetersiz, \%8,8'inin ise fikri olmadığı tespit edilmiştir. Düzenlemeler hakkında bilgi düzeyi yeterli olanların oranı \%35,3 iken, \%2,9'u bilgi düzeyinin çok yeterli olduğunu ifade etmiştir.

Çizelge 5. Kanun hakkında üreticilerin bilgi düzeyleri

\begin{tabular}{lll}
\hline Bilgi Düzeyi & Frekans & Oran (\%) \\
\hline Çok yetersiz & 6 & 8,8 \\
\hline Yetersiz & 30 & 44,1 \\
\hline Fikrim yok & 6 & 8,8 \\
\hline Yeterli & 24 & 35,3 \\
\hline Cok Yeterli & 2 & 2,9 \\
Toplam & $\mathbf{6 8}$ & $\mathbf{1 0 0 , 0}$ \\
\hline
\end{tabular}

Üreticilerin kanun hakkında bilgi edindikleri kaynaklar Çizelge 6'daki gibidir. Buna göre, üreticilerin \%14,7'si bilgi kaynağı olarak televizyonu göstermekteyken, bunu \%5,9 ile Bakanllk personeli ziyareti, \%5,9 ile Resmi Gazete ve \%2,9 ile muhtar takip etmektedir. Üreticilerin \%67'7'si ise diğer bilgi kaynakları yoluyla kanundan haberdar olduklarını belirtmişlerdir.

Çizelge 6. Üreticilerin kanundan haberdar olma yollar1

\begin{tabular}{lll}
\hline Haber Kaynakları & Frekans & Oran (\%) \\
\hline Bakanlık ziyareti & 4 & 5,9 \\
\hline Muhtar & 2 & 2,9 \\
\hline Resmi Gazete & 4 & 5,9 \\
\hline Basın & 2 & 2,9 \\
\hline Televizyon & 10 & 14,7 \\
\hline Diğer (Tapu, emlakçı vd.) & 46 & 67,7 \\
\hline Toplam & $\mathbf{6 8}$ & $\mathbf{1 0 0 , 0}$ \\
\hline
\end{tabular}

Mülkiyet devrinde anlaşma sağlanması durumu

Varisler arası anlaşma sağlanması durumuna bakılarak mirasa konu arazilerin intikalsiz olarak işlenme durumları incelendiğinde, intikalsiz işlenme süresi çoğunlukla $(\% 69,2)$ bir yılın altında gerçekleşmiştir (Çizelge 7). Varislerin \%19,2'si 1-2 yıl arası intikal yapılmadan arazinin işlendiğini belirtirken, \%11,5' 3-5 yıl arasında intikal yapılmadan arazinin işlendiğini belirtmişlerdir. Araştırma kapsamında, 5 yılın üstünde intikal yapılmadan arazi işleyen varis bulunmamaktadır.

Çizelge 7. Üreticilerin miras kalan arazileri intikal yapılmadan işleme süreleri

\begin{tabular}{lll}
\hline İşleme Süresi (yl) & Frekans & Oran (\%) \\
\hline$<1$ & 36 & 69,2 \\
\hline $1-2$ & 10 & 19,2 \\
\hline $3-5$ & 6 & 11,5 \\
\hline $6-10$ & 0 & 0,0 \\
\hline$>10$ & 0 & 0,0 \\
\hline Toplam & $\mathbf{5 2}$ & $\mathbf{1 0 0 , 0}$ \\
\hline
\end{tabular}

Üreticilerin kanunun öngördüğü süreler içinde miras kalan tarım arazilerinin devir işlemelerini tamamlayanların \%42,3'ü (22 üretici) 1-6 ay, \%7,7'si (4 üretici) $7-12$ ay ve $\% 3,8$ 'i (2 üretici) ise 16 ay ve daha fazla süre içinde tamamladıklarını belirtmişlerdir. Üreticilerin \%46,2'si (24 üretici) ise devir işlemlerininin sürdüğünü ifade etmişlerdir.

Kanunun sunduğu mülkiyet devri seçenekleri üzerinde anlaşma sağlayarak tapuya intikal başvurusu yapan varis üreticilerin \%69,2'sinin birden fazla mirasçıya devir tercihinde bulundukları öne çıkmıştır (Çizelge 8).

Anlaşmalı devir seçeneklerinin yeterliliği hakkında üreticilerin tutumları ise; \%19,2'si anlaşmalı devir seçeneklerini çok yetersiz, $\% 30,8$ 'i yetersiz bulmakta iken, \%46,2'si devir seçeneklerini yeterli bulmaktadır. Aralarında anlaşma sağlayan varislerin \%3,8'u ise devir seçeneklerinin yeterliliği konusunda kararsız olduklarını ifade etmişlerdir. 
Çizelge 8. Anlaşma sağlayan üreticilerin devir seçenekleri tercihleri

\section{Anlaşmalı Devir Seçenekleri}

Mirasçıların Üzerinde Anlaşarak Tercih Ettikleri Seçenekleri

Frekans

a. Tek mirasçı

b. Birden fazla mirasçı

c. Aile malları ort.

d. Limited Şti.

e. Üçüncü kişilere satış

Devir tercihi onayı ilçe müd. tarafından henüz alınmadı.

Toplam

\section{Mülkiyet devrinde anlaşmazlık durumu}

Mirasa konu arazilerin devrinde anlaşmazlık yaşayan üreticilerin \%50,0'si miraslı arazileri 1-2 yıl içinde intikal başvurusu yapılmadan işlediklerini belirtmişlerdir (Çizelge 9). Varislerin \%37,5’i 1 yıldan az süre arazisini işlediğini ifade ederken, \%12,5’i 3-5 yıldır arazisini intikalsiz işlediğini söylemiştir.

Çizelge 9. Üreticilerin mirasa kalan arazileri intikalsiz işleme süresi

\begin{tabular}{lll}
\hline İşleme Süresi (yll) & Frekans & Oran (\%) \\
\hline$<1$ & 6 & 37,5 \\
\hline $1-2$ & 8 & 50,0 \\
\hline 3-5 & 2 & 12,5 \\
\hline Toplam & $\mathbf{1 6}$ & $\mathbf{1 0 0 , 0}$ \\
\hline
\end{tabular}

Miras kalan arazilerin devrinde anlaşmazlık yaşayan üreticilerin, diğer varisler ile henüz mevcut devir tercihlerinin bulunmamasına karşın, bu kararın kendilerine bırakılması halinde devir seçeneklerine ilişkin tercih eŏgilimleri Çizelge 10'da görüldüğü gibi belirlenmiştir.

Anlaşmazlğga düssen üreticilerin anlaşmalı devir seçeneklerinin yeterliliği hakkında tutumları ise;

6 \\ 6}

36

0

0

0

10

52

\section{1,5}

69,2

0,0

0,0

0,0

19,2

100,0

\%37,5'i anlaşmalı devir seçeneklerini kesinlikle yetersiz bulurken, $\% 50$ 'si yetersiz bulmakta ve $\% 12,5$ 'i de devir seçeneklerini yeterli bulmaktadır.

Üreticilerin anlaşmazlık nedenleri ve çözüme yönelik tercih eğilimlerinde, miraslı arazilerin mülkiyeti için devir seçenekleri tercihi konusunda uzlaşmaya varamayan üreticilerin tamamı (16 üretici) anlaşmazlığın diğer varislerden kaynaklandığını belirtmişlerdir. Üreticilerin anlaşmalı devir seçenekleri konusunda kissisel ilişskilerden kaynaklı anlaşmazlığa düşme nedenleri önem derecelerine göre Çizelge 11'de verilmiştir. Buna göre öne çıkan en önemli anlaşmazlık nedeni olarak \%37,5 ile baba toprağından vazgeçememe olduğu görülmektedir.

Üreticilerin kişisel ilişkilerden kaynaklı anlaşmazlık durumlarına karşı çözüm tercihlerinde ise üreticilerin \%50'si hiçbir şey yapmadan beklediklerini ifade etmiştir. Ayrıca, saha bulgularına göre, mülkiyet devri tamamlanmayan araziler için kanunda öngörülen devir sürelerinin aşılmasına rağmen şimdiye kadar Bakanlık tarafından dava açılmadığı tespit edilmiştir. Üreticilerin Kanun kaynaklı anlaşmazlık konuları ve çözüme yönelik tercih eğilimlerinde, diğer varisler ile olan anlaşmazlık durumlarında Kanun kaynaklı seçenek tercihleri Çizelge 12'de gösterilmektedir.

Çizelge 10. Anlaşmazlığa düşen üreticilerin miraslı araziler için devir tercihi eğilimleri

\section{Tercih Eğilimleri}

\begin{tabular}{|c|c|c|c|c|c|c|}
\hline \multirow{2}{*}{$\begin{array}{l}\text { Anlaşmalı Devir } \\
\text { Seçenekleri }\end{array}$} & \multicolumn{2}{|c|}{ 1.Tercih } & \multicolumn{2}{|l|}{ 2.Tercih } & \multicolumn{2}{|c|}{ 3.Tercih } \\
\hline & 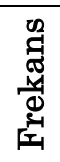 & 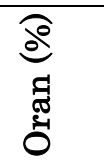 & 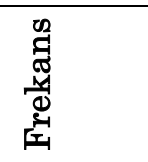 & 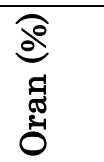 & 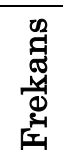 & 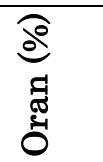 \\
\hline a. Tek mirasçı & 4 & 25,0 & 4 & 25,0 & 4 & 25,0 \\
\hline b. Birden fazla mirasçı & 8 & 50,0 & 8 & 50,0 & 8 & 50,0 \\
\hline c. Aile malları ort. & 0 & 0,0 & 0 & 0,0 & 0 & 0,0 \\
\hline d. Limited Şti. & 0 & 0,0 & 0 & 0,0 & 0 & 0,0 \\
\hline e. 3.kişilere satış & 4 & 25,0 & 4 & 25,0 & 4 & 25,0 \\
\hline Toplam & 16 & 100,0 & 16 & 100,0 & 16 & 100,0 \\
\hline
\end{tabular}


Çizelge 11. Üreticilerin kişisel kaynaklı anlaşmazlık durumları

\begin{tabular}{|c|c|c|c|c|c|c|}
\hline \multirow[b]{2}{*}{ Anlaşmazlık Nedenleri } & \multicolumn{2}{|c|}{ Çok Önemli } & \multirow{2}{*}{ 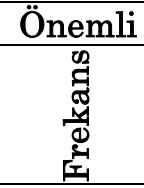 } & \multicolumn{3}{|c|}{ Az Önemli } \\
\hline & 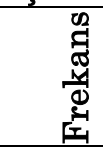 & อี๊ & & రึ๊ & 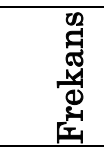 & 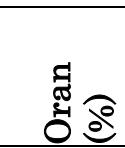 \\
\hline $\begin{array}{l}\text { a. Baba toprağından vazgeçmek istemediğim için } \\
\text { anlaşamadık. }\end{array}$ & 6 & 37,5 & 6 & 37,5 & 0 & 0,0 \\
\hline $\begin{array}{l}\text { b. Miras kalan arazilerin değerleri arasında ciddi } \\
\text { farklar olduğu için anlaşamadık. }\end{array}$ & 0 & 0,0 & 6 & 37,5 & 0 & 0,0 \\
\hline $\begin{array}{l}\text { c. Mirasçılar arasında ihtilaf/küslük olduğu için } \\
\text { anlaşamadık. }\end{array}$ & 2 & 12,5 & 0 & 0,0 & 0 & 0,0 \\
\hline $\begin{array}{l}\text { d. Kanun öncesi hisseli bölüşüm yapanlar tarafından } \\
\text { yeni kanunun mirasçıları mağdur ettiği kıyası } \\
\text { yapıldığı için anlaşamadık. }\end{array}$ & 2 & 12,5 & 2 & 12,5 & 2 & 12,5 \\
\hline e. Diğer & 6 & 37,5 & 2 & 12,5 & 14 & 87,5 \\
\hline Toplam & 16 & 100,0 & 16 & 100,0 & 16 & 100,0 \\
\hline
\end{tabular}

Çizelge 12. Üreticilerin kanundan kaynaklı anlaşmazlık durumları

\begin{tabular}{lllll}
\hline \multirow{2}{*}{ Anlaşmazlığa Yol Açtığı Düşünülen Yasal Durumlar } & 1.Tercih & \multicolumn{3}{c}{ 2. Tercih } \\
\cline { 2 - 5 } & Frekans & Oran (\%) & Frekans & Oran (\%) \\
\hline a. Asgari tarımsal arazi büyüklük sınırı anlaşmazlı̆̆̆ & 4 & 25,0 & 2 & 12,5 \\
\hline b. Yeter gelirli tarımsal arazi büyüklük sınırı anlaşmazlığ 1 & 8 & 50,0 & 4 & 25,0 \\
c. Ekonomik bütünlük sınırlılıkları anlaşmazlığı & 0 & 0,0 & 0 & 0,0 \\
\hline d. Anlaşmalı devir seçenekleri uygunsuzluğu & 4 & 25,0 & 4 & 25,0 \\
\hline e. Diğer & 0 & 0,0 & 6 & 37,5 \\
\hline Toplam & 16 & $\mathbf{1 0 0 , 0}$ & $\mathbf{1 6}$ & 100,0 \\
\hline
\end{tabular}

Buna göre, üreticilerin yarısı yeter gelirli tarımsal arazi büyüklük sınırı nedeniyle anlaşmazlık yaşadıklarını belirtirken, $\% 25$ 'i mülkiyet devri konusunda anlaşmaya varılamamasındaki diğer bir kanuni neden olarak anlaşmalı devir seçeneklerinin fiili bölüşüme uygun olmadığını ifade etmişlerdir.

Üreticilerin kanunda sunulan anlaşmazlık hali çözüm önerilerine ilişsin tercih eğilimleri Çizelge 13’teki gibidir. Üreticilerin \%62,5’i mirasçılar arasında anlaşma sağlanmaması halinde çözüm olarak varislerin sulh hukuk mahkemesine dava açması tercihinde bulunmuşlardır.

Anlaşmazlık durumlarına ilişkin üretici tutum eğilimleri

Mülkiyet devri işlemleri için kanunun öngördüğü mevcut yasal sürelere karşı üreticilerin tutumlarına bakıldığında üreticilerin \%50'si verilen süreleri yetersiz ve diğer \%50'si ise yeterli görmektedir (Çizelge 14).

Üreticilerin Bakanlığın dava açma yetkisi hakkındaki tutumlarında üreticilerden \%50'si devir işlemi tamamlanmayan araziler için Bakanlığın dava açma yetkisi olması gerekliliğine kesinlikle katılmıyorken, \%11,8'i katılmaktadır. Mevcut düzenlemede Bakanlığın sahip olduğu bu yetkiye üreticilerin \%17,66'sı katıldığını, \%14,7'si kesinlikle katıldığını ifade etmiştir. Üreticilerin \%5,92'u ise bu konuda kararsızdır (Çizelge 15).

Kanun kapsamında öne çıkan satış izni uygulaması hakkında tarım arazisinin başka birine devri için Bakanlıktan izin alınması konusunda üreticilerin \%40'ı kesinlikle katılmadıkları yönünde tutum ortaya koymuşlardır (Çizelge 16).

Ehil mirasçı kritelerine ilişkin üreticilerin tutum eğilimleri

Mirasçıların veya Bakanlığın dava açması halinde hakimin kararının belirlenmesinde önceliğin ehil olan mirasçıya verilmesinde ehil mirasçı kriterleri hakkında üreticilerin \%79,4'ü bilgi düzeylerinin yetersiz olduğunu belirtmişlerdir (Çizelge 17).

Ehil mirasçı kriterlerinin belirlenmesinde Yönetmelik ile getirilen puanlama sistemine, üreticilerin \%61'i katılmadıklarını ifade etmişlerdir (Çizelge 18).

Arazi Büyüklük Sınırlılıklarına ilişkin üretici tutum eğilimleri

Antalya ili için belirlenen örtüaltı arazi büyüklük sınırlamaları hakkında üreticiler, asgari tarımsal arazi büyüklügünün 3 dekar olmasını $\% 52,9$ oranında kesinlikle yetersiz bulmaktadır. Yeter gelirli arazi büyüklük sınırı (3 dekar) için üreticilerden $\% 52,9^{\prime}$ u bu büyüklüğün kesinlikle yetersiz olduğunu belirtmiştir (Çizelge 19). 
Çizelge 13. Üreticilerin kanundan kaynaklı anlaşmazlıklara ilişkin çözüm tercihleri

\begin{tabular}{|c|c|c|c|c|c|c|}
\hline \multirow[b]{2}{*}{ Anlaşmazlık Hali Çözüm Seçenekleri } & \multicolumn{2}{|c|}{ 1.Tercih } & \multicolumn{2}{|c|}{ 2.Tercih } & \multicolumn{2}{|c|}{ 3.Tercih } \\
\hline & 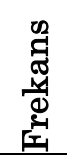 & 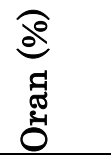 & 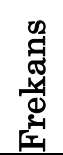 & 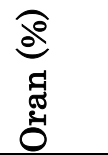 & 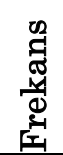 & 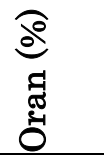 \\
\hline a. Varislerin dava açması & 10 & 62,5 & 0 & 0,0 & 6 & 37,5 \\
\hline b. Bakanlık çözsün, gerekirse dava açsın & 4 & 25,0 & 8 & 50,0 & 4 & 25,0 \\
\hline c. Hakim karar versin & 2 & 12,5 & 8 & 50,0 & 6 & 37,5 \\
\hline Toplam & 16 & 100,0 & 16 & 100,0 & 16 & 100,0 \\
\hline
\end{tabular}

Çizelge 14. Miraslı arazilerde mülkiyet devri işlemleri için tanınan yasal sürelere karşı üretici tutumları

\begin{tabular}{lll}
\hline Üreticilerin Tutum Eğilimleri & Frekans & Oran (\%) \\
\hline Kesinlikle yetersiz & 12 & 17,6 \\
\hline Yetersiz & 22 & 32,4 \\
\hline Fikrim yok & 2 & 2,9 \\
\hline Yeterli & 20 & 29,4 \\
\hline Kesinlikle Yeterli & 12 & 17,6 \\
\hline Toplam & 68 & 100,0 \\
\hline
\end{tabular}

Çizelge 15. Bakanlığın dava açma yetkisi hakkında üretici tutumları

\begin{tabular}{lll}
$\begin{array}{l}\text { Üreticilerin Tutum } \\
\text { Eğilimleri }\end{array}$ & Frekans & Oran (\%) \\
\hline Kesinlikle katılmıyorum & 34 & 50,0 \\
\hline Katılmıyorum & 8 & 11,8 \\
\hline Kararsızım & 4 & 5,9 \\
\hline Katılıyorum & 12 & 17,6 \\
\hline Kesinlikle Katılıyorum & 10 & 14,7 \\
\hline Toplam & $\mathbf{6 8}$ & $\mathbf{1 0 0 , 0}$ \\
\hline
\end{tabular}

Çizelge 16. Bakanlığın satış izni uygulaması hakkında üretici tutumları

\begin{tabular}{lll}
\hline $\begin{array}{l}\text { Üreticilerin Tutum } \\
\text { Eğilimleri }\end{array}$ & Frekans & Oran (\%) \\
\hline Kesinlikle katılmıyorum & 40 & 58,8 \\
\hline Katılmıyorum & 18 & 26,5 \\
\hline Kararsızım & 0 & 0,0 \\
\hline Katıliyorum & 10 & 14,7 \\
\hline Kesinlikle Katılıyorum & 0 & 0,0 \\
\hline Toplam & $\mathbf{6 8}$ & $\mathbf{1 0 0 , 0}$ \\
\hline
\end{tabular}

Çizelge 17. Üreticilerin ehil mirasçı kriterleri hakkında bilgi düzeyleri

\begin{tabular}{lll}
\hline $\begin{array}{l}\text { Üreticilerin Tutum } \\
\text { Eğilimleri }\end{array}$ & Frekans & Oran (\%) \\
\hline Çok yetersiz & 34 & 50,0 \\
\hline Yetersiz & 20 & 29,4 \\
\hline Yorum yok & 8 & 11,8 \\
\hline Yeterli & 6 & 8,8 \\
\hline Kesinlikle yeterli & 0 & 0,0 \\
\hline Toplam & $\mathbf{6 8}$ & $\mathbf{1 0 0 , 0}$ \\
\hline
\end{tabular}

Çizelge 18. Ehil mirasçının belirlenmesinde puanlama sisteminin yapılması hakkında üretici tutumları

\begin{tabular}{lll}
\hline $\begin{array}{l}\text { Üreticilerin Tutum } \\
\text { Eğilimleri }\end{array}$ & Frekans & Oran (\%) \\
\hline Kesinlikle katılmıyorum & 20 & 29,4 \\
\hline Katılmıyorum & 20 & 29,4 \\
\hline Kararsızım & 12 & 17,6 \\
\hline Katıliyorum & 14 & 20,6 \\
\hline Kesinlikle Katılıyorum & 2 & 2,9 \\
\hline Toplam & $\mathbf{6 8}$ & $\mathbf{1 0 0 , 0}$ \\
\hline
\end{tabular}

Örtüaltı arazilerinde ekonomik bütünlük kabul edilen sınırlar hakkında üreticilerin \%32,4'ü sınırdaş olmayan araziler arasındaki mesafenin $10 \mathrm{~km}$ 'den az olmasını kesinlikle yetersiz karşılamışlardır. Sınırdaş olmayan örtüaltı arazisinin ise minimum büyüklüğünün 1 dekar ve üstü olması halinde ekonomik bütünlük oluşturacağı hususunda da üreticilerin $\% 35,1$ 'i bu sinırı yeterli olarak bulmuşlardır (Çizelge 20).

Arazi edindirme iş ve işlemleri hakkında üreticilerin tutum eğilimleri

Mülkiyet devri işlemleri kapsaminda il ve ilçe müdürlükleri tarafından yürütülen arazi edindirme iş ve işlemlerinin başka bir birim tarafından verilmesi halinde üreticilerin bilgi almak için tercihte bulundukları birimler içerisinde önceliğin \%55,9 ile tapu müdürlükleri olduğu ifade edilmiştir. Buna göre, kanun hakkında bilgi almak için 2. ve 3. tercihlerinde ilçe müdürlükleri öne çıkmaktadır (Çizelge 21). 
Çizelge 19. Arazi büyüklük sınırları yeterliliğinde üretici tutumları

\begin{tabular}{|c|c|c|c|c|c|}
\hline \multirow[t]{2}{*}{ Üreticilerin Tutum Eğilimleri } & \multicolumn{2}{|c|}{$\begin{array}{l}\text { Asgari Tarımsal } \\
\text { Büyüklüğü }(3 \mathrm{da})\end{array}$} & \multirow[t]{2}{*}{ Arazi } & \multicolumn{2}{|c|}{$\begin{array}{l}\text { Yeter Gelirli Tarımsal Arazi Büyüklüğü } \\
(3 \mathrm{da})\end{array}$} \\
\hline & Frekans & Oran (\%) & & Frekans & Oran (\%) \\
\hline Kesinlikle yetersiz & 36 & 52,9 & & 36 & 52,9 \\
\hline Yetersiz & 8 & 11,8 & & 8 & 11,8 \\
\hline Kararsızım & 0 & 0,0 & & 0 & 0,0 \\
\hline Yeterli & 20 & 29,4 & & 20 & 29,4 \\
\hline Kesinlikle yeterli & 4 & 5,9 & & 4 & 5,9 \\
\hline Toplam & 68 & 100,0 & & 68 & 100,0 \\
\hline
\end{tabular}

Çizelge 20. Ekonomik bütünlük kabul edilen sınırların yeterliliğinde üretici tutumları

\begin{tabular}{lllll}
\multirow{2}{*}{ Üreticilerin Tutum Eğilimleri } & \multicolumn{2}{l}{ Max. Parsel Arası } & $\mathbf{2} \mathbf{k m}$ & \multicolumn{2}{l}{$\begin{array}{l}\text { Min. Örtüaltı (sınırdaş olmayan) arazi } \\
\text { büyüklüğ 1 da }\end{array}$} \\
\cline { 2 - 5 } & Frekans & Oran (\%) & Frekans & Oran (\%) \\
\hline Kesinlikle yetersiz & 22 & 32,4 & 22 & 32,4 \\
\hline Yetersiz & 14 & 20,6 & 14 & 20,6 \\
Kararsızım & 0 & 0,0 & 0 & 0,0 \\
\hline Yeterli & 22 & 32,4 & 24 & 35,3 \\
\hline Kesinlikle yeterli & 10 & 14,7 & 8 & 11,8 \\
\hline Toplam & $\mathbf{6 8}$ & $\mathbf{1 0 0 , 0}$ & $\mathbf{6 8}$ & $\mathbf{1 0 0 , 0}$ \\
\hline
\end{tabular}

Çizelge 21. Üreticilerin kanun hakkında bilgi almak istedikleri birim tercihleri

\begin{tabular}{lllllll}
\multirow{2}{*}{ Bilgi alınacak birimler } & 1.Tercih & \multicolumn{3}{c}{ 2.Tercih } & 3.Tercih & \\
\cline { 2 - 7 } & Frekans & Oran (\%) & Frekans & Oran (\%) & Frekans & Oran (\%) \\
\hline a. Muhtarlıktan & 4 & 5,9 & 10 & 14,7 & 2 & 2,9 \\
b. İlce tarımdan & 16 & 23,5 & 20 & 29,4 & 20 & 29,4 \\
\hline c. İl tarımdan & 4 & 5,9 & 2 & 2,9 & 8 & 11,8 \\
\hline d. Ziraat Odası (il-ilçe) & 0 & 0,0 & 8 & 11,8 & 2 & 2,9 \\
\hline e. Kaymakamlktan & 0 & 0,0 & 8 & 11,8 & 0 & 0,0 \\
\hline f. Kooperatiflerden & 0 & 0,0 & 0 & 0,0 & 2 & 2,9 \\
g. Tapudan & 38 & 55,9 & 10 & 14,7 & 12 & 17,6 \\
h. İnternetten & 2 & 2,9 & 2 & 2,9 & 10 & 14,7 \\
1. Diğer & 4 & 5,9 & 8 & 11,8 & 12 & 17,6 \\
Toplam & $\mathbf{6 8}$ & $\mathbf{1 0 0 , 0}$ & $\mathbf{6 8}$ & $\mathbf{1 0 0 , 0}$ & $\mathbf{6 8}$ & $\mathbf{1 0 0 , 0}$ \\
\hline
\end{tabular}

Arazi parçalanmasının önlenmesi hakkında uygulamaya yönelik genel görüşler

Kanunun tarım arazilerinin parçalanmasını engellemesi konusunda üreticilerin \% 47'sinin bu konuya katıldıkları belirlenirken, \%23,5'inin ise kanunun toprağın parçalanmasını önleyeceğine katılmadıkları görülmüştür (Çizelge 22).

Satış yoluyla mülkiyet devrinde öne çıkan üretici tutumu bulguları

Satışla devir amaçlı başvuru yapmış 20 üretici ile yapılan görüşmeler neticesinde elde edilen bulgulara göre;

- Satış izni uygulamasından haberdar olma konusunda üreticilerin bilgi kaynağ ${ }_{1}$ olarak ilk sırada \%70 ile tapu müdürlükleri gelirken, \%30 ile ilçe tarım ikinci sırada yer almaktadır.

- Satışa konu tarım arazilerini kimin satın aldığı hususunda da satın alan kişilerin \%60'si diğer yatırımcı, \% 30’u diğer tarımcı ve \%10’u hissedardır.
- Üreticiler tarafından arazi satışı için ilk başvurulan kamu biriminin \%90'ı tapu müdürlükleri iken \%10’u da Tarım ve Ormancılık Bakanlığı İlçe Müdürlükleri olduğu yönündedir.

Satışa konu araziler için bakanlıktan izin alınması konusunda ise üreticilerin tutumu Çizelge 23'te sunulmuştur. Buna göre, üreticilerin $\% 60$ ' uygulamasına kesinlikle katılmadıklarını belirtmişlerdir.

Tarımsal bir arazinin satılması halinde, hissedarın veya sınırdaş olan diğer tarımsal arazi sahibinin satın alma önceliğinin olması konusunda (şuf'a hakkı) üreticilerin tutumları katıldıkları yönünde olmuştur (Çizelge 24).

Üreticilerin tarımsal faaliyeti sonlandırmadaki tercih eğilimlerinin oranları Çizelge 25'te verilmiştir. Buna göre, üreticilerden \%70'inin en önemli tercih nedeni olarak ekonomik sorunlardan dolayı tarımsal faaliyeti sonlandıracaklarını belirtmişlerdir. 
Çizelge 22. Kanunun tarım arazilerinin parçalanmasını engellemesi konusunda üreticilerin tutumu

\begin{tabular}{lll}
\hline $\begin{array}{l}\text { Üreticilerin Tutum } \\
\text { Eğilimleri }\end{array}$ & Frekans & Oran (\%) \\
\hline Kesinlikle katılmıyorum & 6 & 8,8 \\
\hline Katılmıyorum & 16 & 23,5 \\
\hline Kararsızım & 10 & 14,7 \\
\hline Katıliyorum & 32 & 47,1 \\
\hline Kesinlikle Katılıyorum & 4 & 5,9 \\
\hline Toplam & $\mathbf{6 8}$ & $\mathbf{1 0 0 , 0}$ \\
\hline
\end{tabular}

Çizelge 24. Şuf’a (ön alım hakkı) konusunda üretici tutumları

\begin{tabular}{lll}
$\begin{array}{l}\text { Üreticilerin Tutum } \\
\text { Eğilimleri }\end{array}$ & Frekans & Oran (\%) \\
\hline Kesinlikle katılmıyorum & 4 & 20,0 \\
\hline Katılmıyorum & 4 & 20,0 \\
\hline Kararsızım & 2 & 10,0 \\
\hline Katılıyorum & 8 & 40,0 \\
\hline Kesinlikle Katılıyorum & 2 & 10,0 \\
\hline Toplam & $\mathbf{2 0}$ & $\mathbf{1 0 0 , 0}$ \\
\hline
\end{tabular}

Çizelge 23. Satışa konu araziler için Bakanlıktan izin alınması hakkında üretici tutumları

\begin{tabular}{lll}
\hline $\begin{array}{l}\text { Üreticilerin Tutum } \\
\text { Eğilimleri }\end{array}$ & Frekans & Oran (\%) \\
\hline Kesinlikle katılmıyorum & 12 & 60,0 \\
\hline Katılmıyorum & 6 & 30,0 \\
\hline Kararsızım & 2 & 10,0 \\
\hline Katıliyorum & 0 & 0,0 \\
\hline Kesinlikle Katıliyorum & 0 & 0,0 \\
\hline Toplam & $\mathbf{2 0}$ & $\mathbf{1 0 0 , 0}$ \\
\hline
\end{tabular}

Çizelge 26. Kanunun tarım arazilerinin parçalanmasını engellemesi hakkında üretici tutumları

\begin{tabular}{lll}
\hline Üreticilerin Tutum Eğilimleri & Frekans & $\mathbf{( \% )}$ \\
\hline Kesinlikle katılmıyorum & 6 & 30,0 \\
\hline Katılmıyorum & 8 & 40,0 \\
\hline Kararsızım & 0 & 0,0 \\
\hline Katılıyorum & 6 & 30,0 \\
\hline Kesinlikle Katılıyorum & 0 & 0,0 \\
\hline Toplam & $\mathbf{2 0}$ & $\mathbf{1 0 0 , 0}$ \\
\hline
\end{tabular}

Çizelge 25. Tarımsal faaliyeti sonlandırma nedenlerinde üreticilerin tercihleri

\begin{tabular}{|c|c|c|c|c|c|c|}
\hline \multirow[b]{2}{*}{$\begin{array}{l}\text { Tarımsal Faaliyeti } \\
\text { Sonlandırma Nedenleri }\end{array}$} & \multicolumn{2}{|l|}{ 1.Tercih } & \multicolumn{2}{|l|}{ 2.Tercih } & \multicolumn{2}{|l|}{ 3.Tercih } \\
\hline & Frekans & $\begin{array}{l}\text { Oran } \\
(\%)\end{array}$ & Frekans & $\begin{array}{l}\text { Oran } \\
(\%)\end{array}$ & Frekans & $\begin{array}{l}\text { Oran } \\
(\%)\end{array}$ \\
\hline Arazim küçük, geçinemiyorum & 2 & 10,0 & 12 & 60,0 & 0 & 0,0 \\
\hline Çok ortaklı, anlaşamıyorum & 0 & 0,0 & 2 & 10,0 & 0 & 0,0 \\
\hline $\begin{array}{l}\text { c. Ailem şehirde yaşıor, burada başka } \\
\text { kimsem yok }\end{array}$ & 0 & 0,0 & 2 & 10,0 & 0 & 0,0 \\
\hline Şehirde işim var & 4 & 20,0 & 0 & 0,0 & 0 & 0,0 \\
\hline Daimi ikametim şehir & 0 & 0,0 & 2 & 10,0 & 2 & 10,0 \\
\hline Diğer (Ekonomik sorunlar vd.) & 14 & 70,0 & 2 & 10,0 & 18 & 90,0 \\
\hline Toplam & 20 & 100,0 & 20 & 100,0 & 20 & 100,0 \\
\hline
\end{tabular}

Satışla devir amaçlı başvuran üreticilerde kanunun tarım arazilerinin parçalanmasını engellemesi konusunda toplamda \%70'inin parçalanmayı önleyeceğine katıldıkları görülmüştür (Çizelge 26).

\section{SONUÇ ve ÖNERILER}

\section{Sonuçlar}

Tarımsal arazilerin miras ve satış yoluyla devrinde anlaşmazlık durumlarının tespitinde üreticilerden elde edilen bulgulardan öne çıan temel sonuçlar aşağıda sıralanmıştır:

- Kanuna ekli (1) sayılı listede, Antalya ili, ilçe bazlı örtüaltı arazilerde yeter gelirli tarımsal arazi büyüklüğü olan 3 dekar sinırının, bölgenin iklim ve ekonomik farklılıkları gözetilerek ilçelere göre yeniden belirlemesi gerektiği yaygin kanaat olarak öne çıkarken, üreticilerin \%52,9'u tarafindan bu sinırın kesinlikle yetersiz bulunduğu belirtilmiştir.

- Kanunun 5 inci maddesi hükümlerince belirlenen anlaşmalı devir seçeneklerinin yeterliliğini, miraslı arazilerde anlaşma sağlayan üreticilerin $\% 46,2$ 'si yeterli bulurken, anlaşmazlık yaşayan üreticilerden $\% 50$ 'si tarafindan yetersiz karşılanmıştır.

- Miraslı arazilerde, mülkiyet devri konusunda varislerden ziyade kanundaki devir seçeneklerinden kaynaklı anlaşmazlıkların yaşandiğ görülmüş, üreticilerden \%50'sinin arazi büyüklük sınırları nedeniyle anlaşmazlığa düştükleri saptanmıştır.

- Henüz devir tercihi yapılmayan miraslı arazilerde, tercih kararı konusunda varisler arasında anlaşmazlık yaşanması nedeniyle, üreticilerden bazılarının topră̆g işlemeyi biraktıkları ifade edilmiştir.

- Kanunun öngördüğü devir seçeneklerinin tercihinde, üreticilerin karar vermede zorlanma nedenleri, mirasa konu olan arazilerin fiili bölüşümlerini diğer varislerle çok daha önce yaptıkları için mülkiyet devri işlemlerini bu paylaşıma göre tamamlayamadıkları anlaşılmıştır. 
- Yönetmelik ile belirlenen (md.10) ehil mirasçı kriterleri hakkında üreticilerinden neredeyse \%80'inin bilgi düzeylerinin yetersiz olduğu saptanmış, bu konudan haberdar olmadıkları gözlemlenmiştir.

\section{- Tarım arazilerinin satış yoluyla} gerçeklesstirilen devirlerinde, arazilerin hisseli ve parçalanarak satılması sebebi olarak, üreticilerin büyük çoğunluğu, üretim yaptıkları yılın ekonomik koşullarının iyi olmamasından dolayı üretime devam edebilmeleri için satış yolunu tercih etmek zorunda kaldıklarını söylemişlerdir.

- Miraslı arazilerin devir işlemlerinin, Bakanlık yerine yetki olarak sadece tapu müdürlüklerine onay verilerek gerçekleştirilmesi gerektiği ifade edilmiştir. Bununla beraber, kanun uygulaması hakkında bilgi almak istedikleri birim tercihinde de tapu müdürlükleri \%55,9 oranında öne çıkmıştır.

- Miraslı arazilerde üreticilerin \%47,1’i tarafindan bu kanunun uygulanmasiyla, arazi parçalılığının önlenebileceği düşünülse de arazilerin mülkiyet sonrass fiili kullanımlarının kanunun öngördüğ̈̈ devir tercihine göre sürdürülmesinin zor olduğu anlaşılmıştır. Satışla devir yapan üreticilerin \%70'inin ise kanun uygulamasının toprak parçalanmasını engellemeyeceği vurgulanmıştır.

- Üreticiler tarafindan kanunen zorunlu olarak Bakanlık izni alınması nedeniyle resmi isslemlerin beklenenden daha uzun sürede tamamlandı̆̆g belirtilmiştir. Bununla beraber, üreticilerden \%60'ı (hem miras hem de satış anket bulgularında) Bakanlık izni uygulamasina kesinlikle katılmadıklarını belirtilmiştir.

\section{Öneriler}

- Miraslı ve satışla devirlerde ortaya çıkan anlaşmazlık durumlarının ortadan kaldırılması ve Kanun uygulamasının daha sağlıklı bir şekilde sürdürülmesi için araştırma bulguları ve saha gözlemlerine dayanarak aşağıdaki öneriler geliş̧tirilmiştir:

- $\quad$ Kanunun 4 üncü bölgeye göre belirlenen arazi büyüklük sinırlarının yeniden gözden geçirilmesi gerekliliğı ortaya çıkmıştır. Özellikle örtüaltında, 12 ay boyunca üretim yapılabilen yerler için arazi ekonomik büyüklükleri yeniden belirlenmelidir.

- Mülkiyeti ihtilaflı olan ve mirasa konu tarım arazilerinde, kanunun 8/B maddesinde geçen mirasçıların anlaşma sağlayarak mirasın açılmasından 1 yıl içinde mülkiyet devri işlemlerini tamamlamalarında mirasçıların isteğine bağlı kalmadan, Bakanlık sürece dahil olup arabuluculuk görevi yapmalıdır. $\mathrm{Bu}$ anlamda, devir işlemlerinin daha kısa sürede tamamlanması söz konusu olacaktır.

- Miraslı tarım arazilerinde, kanunun 8/Ç maddesi gereğince mirasçıların anlaşmaları için verilen yasal süreler içinde mülkiyet devri tamamlanmayan arazilerin tespiti halinde, Bakanlı̆̆ın dava açmak yerine, kanun öncesi ve sonrasında açılmıs olan ve uzayan miras davalarına müdahil olarak, mahkeme kararının kısa sürede sonuca ulaşmasına katkı vermelidir.

- Kanun uygulamasindan haberdar olmayan mirasçıların, uygulama sürecine bir an önce dahil edilebilmeleri için Bakanlığın mirasçılara tebligat aracılığıla bildirimde bulunarak devir için ek süre tanımak yerine (Resmi Gazete 2014a, madde 8/Ç) mirasın açılmasından itibaren hemen tebligat gönderecek bir sistemi uygulamaya dahil etmesi önerilmektedir.

- Yönetmeliğin 10 uncu maddesinde belirlenen ehil mirasçı kriterlerinin, üretici örgütlerinin de görüsleri alınarak daha kolay uygulanabilir hale ve sadeleştirilmişs bir şekle dönüştürülmesi düşünülmelidir. Bu haliyle tarafları memnun edecek ve ehil ayırımını sağlayacak bir yapı olduğu konusunda çok ciddi bir ayrışma gözlemlenmiştir.

- Mülkiyet devri işlemlerinin daha kısa sürede yapılabilmesi için; tapu müdürlüklerine yapılan intikal başvurularının ayrıca Bakanlığa bildirilmesi nedeniyle, izin işlemlerinin resmi yazışmalarla uzatılması yerine, tapu müdürlüklerinde de arazi edindirme ofisleri kurularak devir amaçl başvuruların değerlendirilmesi yapılabilmelidir.

- Kanunun 8/I maddesinde geçen tarımsal arazilerin satılması halinde sinırdas arazi sahiplerine tanınan ön alım önceliği için Bakanlık desteğiyle kredi desteği verilmesi, mevcut arazilerini büyütmek isteyen sınırdaş arazi malikleri açısından olumlu karşılanacağı düşünülmektedir.

- Araştırma amaçlı ziyaret edilen ilçe müdürlüklerinde kanun uygulaması kapsamında hizmet veren bakanlık personeli sayısının yeterli olmadığı gözlemlenmiştir. $\mathrm{Bu}$ konuda bakanlık personeli sayısının güçlendirilmesiyle birlikte bölgedeki üreticilere özellikle miras kalan araziler için kanunun uygulamada getirdiği değişikler hakkında daha sık bilgilendirilme yapılması, nitekim kanunun uygulama sürecinin vatandaş-Bakanlık açısından daha sağlıklı bir şekilde sürdürülmesine katkı sağlayacağı öngörülmektedir. $\mathrm{Bu}$ anlamda, üretici örgütleri ve ziraat odaları gibi kuruluşlardan da destek alınmalıdır.

\section{TEȘEKKÜR}

Bu çalışma; Akdeniz Üniversitesi Bilimsel Araştırma ve Koordinasyon Birimi tarafindan desteklenen, FYL 2018 - 3241 no'lu, "Tarım Arazilerinin Miras Yolu İle Bölünmesinin Önlenmesine Yönelik Yasal Düzenlemenin Örtüaltı İşletmeleri Üzerindeki Etkilerinin Araştırılması: Antalya İli Örneği” adlı Yüksek Lisans Tez Projesi verilerinden faydalanarak yapılmıştır. 


\section{KAYNAKLAR}

Anonim 2017. Tarım Reformu Genel Müdürlüğü. 6537 sayılı kanun uygulamalarına ilişkin veriler, (yayımlanmamış) Ankara.

Demirtaş E, Sarı M 2003. Arazi toplulaştırması. BATEM, Derim, 20(1): 48-58.

Ekinci K, Sayılı M 2010. Tarım arazilerinin parçalanmasını önlemeye yönelik mevzuat üzerine bir inceleme. GOÜ Ziraat Fakültesi Dergisi, 27(2): 121-129.

Erdoğan K 2016. Tarım arazilerinin miras yoluyla intikali, Selçuk Üniversitesi Hukuk Fakültesi Dergisi, 24 (1): 124-179.

Gün S 2001. Türkiye'de tarım topraklarının mülkiyet durumu ve uygulanan politikalar, Cumhuriyetin 100. Yilında Türk Tarımının Hedefleri Sempozyumu, ss.325-336, Ankara.

Özay Oİ 2015. Tarım İşletmelerinin ve Arazilerinin Miras Yoluyla İntikali. Yetkin Yayınları, Ankara.

Özçelik BŞ 2015. 5403 Sayılı Toprak Koruma ve Arazi Kullanımı Kanunu'nda 6537 Sayılı Kanun'la yapılan değişiklikler ve değerlendirilmesi. Gazi Üniversitesi Hukuk Fakültesi Dergisi. 19(1):87110.

Resmi Gazete 1926. Türk Medeni Kanunu (No:743), Tarih:04.04.1926, Sayı:339, Ankara.

Resmi Gazete 1985. İmar Kanunu (No:3194), Tarih:03.05.1985, Sayı: 18749, Ankara.

Resmi Gazete 2001. Türk Medeni Kanunu (No:4721), Tarih:08.12.2001, Sayı:24607, Ankara.

Resmi Gazete 2005. Toprak Koruma ve Arazi Kullanımı Kanunu (No:5403),Tarih:19.07.2005, Sayı:25880, Ankara.

Resmi Gazete 2007. Toprak Koruma ve Arazi Kullanımı Kanununda Değişiklik Yapılmasına Hakkında Kanun (No:5578), Tarih:09.02.2007, Sayı:26429, Ankara.

Resmi Gazete 2009. Tarım Arazilerinin Korunması, Kullanılması ve Arazi Toplulaştırmasına İlişkin Tüzük, Tarih:24.07.2009, Sayı:27298,Ankara.
Resmi Gazete 2014a. Toprak Koruma ve Arazi Kullanımı Kanununda Değişiklik Yapılmasına Hakkında Kanun (No:6537), Tarih:05.05.2014, Sayı:29001, Ankara.

Resmi Gazete 2014b. Tarımsal Arazilerin Mülkiyetinin Devrine İlişkin Yönetmelik, Tarih:31.12.2014, Sayi:29222, Ankara.

Resmi Gazete 2015. Tarımsal Arazilerin Mülkiyetinin Devrine İlişkin Uygulama Talimatı, Tarih:03.02.2015, Ankara.

Resmi Gazete 2017. Tarımsal Arazilerin Mülkiyetinin Devrine İlişkin Uygulama Talimatı, Tarih:03.11.2017, Ankara.

Resmi Gazete 2018a. Tarmmsal Arazilerin Mülkiyetinin Devrine İlişkin Uygulama Talimatı, Tarih: 02.01.2018, Ankara.

Sayın C, Kavasoğlu İ 2016 . Tarımda Yeni Miras Kanunu ve Olası Sonuçları. Türkiye XII. Tarım Ekonomisi Kongresi, Isparta. 2: 943-950.

Sayın C, Altunkaya M, Taşcıoğlu Y, Sav O, Kavasoğlu İI 2017. Türkiye'de toprak parçalanması ve miras hukuku. Akdeniz Ziraat Bilimleri Dergisi, 30(3): 213-218.

Sayın C 2018. Tarım Hukuku Dersi Notları, Akdeniz Üniversitesi Ziraat Fakültesi Tarım Ekonomisi Bölümü, Antalya.

Tarım ve Ormancılık Bakanlığı 2013. Tarım Arazilerinin Bölünmesinin Önlenmesine Yönelik Yasal Düzenleme Hakkında Düzenleyici Etki Analizi: Yayın No: 210, Ankara.

Tarım ve Ormancılık Bakanlığı 2017. Antalya ili miras ve satış yoluyla mülkiyet devri başvuru sayıları

Ural A, Kilıç I 2013. Bilimsel Araştırma Süreci ve SPSS ile Veri Analizi, Detay Yayıncılık, Ankara, ss. 296.

Yıldız O, Uzun B, Çoruhlu YE 2018. Tarım Arazilerinin Miras yoluyla İntikali ve Sağlararası İşlemlerle Devrine İlişkin Kısıtlamalar. Türkiye Adalet Akademisi Dergisi, 33: 95-121. 